\title{
NON INVASIVE TRANS-CUTANEOUS BILIRUBIN AS A SCREENING TEST TO IDENTIFY THE NEED FOR SERUM BILIRUBIN ASSESSMENT IN HEALTHY TERM NEONATES
}

\author{
Gupta B.K.', Chaudhary N. ${ }^{2}$, Bhatia B.D. ${ }^{3}$, Gupta Binod ${ }^{4}$
}

\begin{abstract}
INTRODUCTION: Hyperbilirubinemia is a common problem in the neonates. It can progress to develop kernicterus unless intervention is initiated. Severity of jaundice and decision for management are usually based on total serum bilirubin (TsB) estimation which technique and results closely correlates with total serum bilirubin levels.

OBJECTIVES: To compare the accuracy of visual assessment of jaundice by single trained observer based on Kramer's index with total serum bilirubin levels in healthy term neonates. To compare accuracy of non invasive bilirubin assessment with serum bilirubin levels, to compare trans-cutaneous bilirubin assessment on different sites (forehead and sternum) and to develop a cutoff point of trans-cutaneous bilirubin level for serum bilirubin assessment.
\end{abstract}

METHODS: This prospective study was conducted in the Neonatal unit of the department of Paediatrics at Kasturba Hospital ,Manipal. Study period was from October 2007 to June 2008. Clinical assessment of jaundice was done in healthy term neonates by observer (Trained Paediatric Post Graduate Resident) based on Kramer's index. Transcutaneous bilirubin assessment was done on the forhead and sternum of each baby using JM-103 Minolta. Air shields bilirubino meter. Serum bilirubin level was measured within 30 minutes of the clinical assessment for each baby.

RESULTS: This study included 187 healthy term neonates. The mean birth weight was $2856.83 \mathrm{gm}+493.89 \mathrm{gm}$ and mean gestation was $38.25+1.030 \mathrm{SD}$. Clinical assessment and Transcutaneous bilirubin(TcB) significantly correlated with total serum bilirubin (TsB), with correlation co-efficient of 0.757 and 0.801 respectively ( $\mathrm{p} 0.0001$ ). Transcutaneous bilirubin assessment over forehead showed a tendency to under estimate total serum bilirubin, with mean difference of $-0.31 \mathrm{mg} / \mathrm{dl}$, SD $1.75 \mathrm{mg} / \mathrm{dl}$ with $95 \%$ confidence interval of the mean -0.60 and $-0.02 \mathrm{mg} / \mathrm{dl}$ (p value 0.05 ). Transcutaneous bilirubin assessments between $10 \mathrm{mg} / \mathrm{dl}$ to $15 \mathrm{mg} / \mathrm{dl}$ correlated accurately with total serum bilirubin levels avoiding blood sampling.

CONCLUSION: Trained observer clinical assessment of jaundice can be used for screening neonatal jaundice. Non invasive transcutaneous bilirubin assessment has demonstrated significant accuracy with serum bilirubin level estimates between 48 hours to 7 days on two different sites forehead and sternum.

KEYWORDS: Hyperbilirubinemia, Serum Bilirubin, Jaundice.

1,2,4. Assistant Professor, Department of Paediatrics, Universal College of Medical Sciences \& Teaching Hospital, Bhairahawa, Nepal

3. Professor and Head, Department of Paediatrics ,Universal College of Medical Sciences \& Teaching Hospital, Bhairahawa, Nepal

\author{
For Correspondence \\ Dr. Badri Kumar Gupta, M.D., \\ Assistant Professor, \\ Department of Paediatrics, \\ Universal College of Medical Sciences \& Teaching Hospital, \\ Bhairahawa, Nepal \\ E-mail:drbadrikgupta@gmail.com
}




\section{INTRODUCTION}

Jaundice comes from the French word 'jaune' which means 'yellow'. When it is said that a baby is jaundiced, it simply means that the colour of the skin appears yellow, which is often seen in the first few days after birth. The yellow colour is due to bilirubin that is produced when red blood cells get old and are broken down by the body.

Jaundice is a common problem in the first week of life. It is a cause of concern for the physician and a source of anxiety for the parents. High bilirubin levels may be toxic to the developing central nervous system and may cause neurological impairment even in term newborns. ${ }^{2}$

Jaundice due to physiological immaturity of newborn babies is seen in nearly $60 \%$ of term and $80 \%$ of pre term. Adults appear jaundiced when the serum bilirubin level is greater than $2 \mathrm{mg} / \mathrm{dl}$, and newborns appear jaundiced when it is greater than $7 \mathrm{mg} /$.

The yellow colour usually results from the accumulation of uncongugated, non polar, lipid-soluble bilirubin pigment in the skin. This unconjugated bilirubin (designated indirect acting by nature of the Van den Bergh reaction) is an end product of heme protein catabolism from a series of enzymatic reactions by heme-oxygenase and biliverdin reductase and non enzymatic reducing agents in the reticulo endothelial cells. It may also be due to part in deposition of pigment from conjugated bilirubin, the end product from indirect, unconjugated bilirubin that has undergone conjugation in the liver cell microsome by the enzyme uridine diphosphoglucuronic acid (UDP) glucornyl transferase to form the polar, water-soluble glucornide of bilirubin (direct reacting). Although bilirubin may have a physiologic role as an anti-oxidant, elevated levels of indirect, unconjugated bilirubin are potentially neuro-toxic. Even though the conjugated form is not neuro toxic, direct hyperbilirubinemia indicates potentially serious hepatic disorder or systemic illness. ${ }^{4}$

One simple approach that has been used elsewhere to determine the need for serum bilirubin testing is the progression of yellow discolouration of the skin from cepahlocaudal progression using the Kramer's rule. The scale is based on a 1969 study of 108 full term infants which found that bilirubin concentrations correlated to 5 specific 'dermal zones' (1) head and neck, (2) upper trunk, (3) lower trunk and thighs, (4) arms and legs below the knees, (5) hands and feet. Lowest total serum bilirubin levels were associated with yellow disclouration of the head and neck only and highest levels where the disclouration extended to the hands and feet.
Transcutaneous bilirubinometer (TcB; Minolta Air shields Jaundice meter) proved to be a useful new device for the clinical screening of neonatal jaundice. It is non-invasive, non traumatic and easy to operate. Study demonstrated a good correlation between transcutaneous bilirubinometer reading and serum bilirubin. ${ }^{6}$ The transcutaneous bilirubinometer is a reflectometer which permits the non invasive monitoring of neonatal hyper bilirubinemia. ${ }^{7}$

Figure 1: JM-103 Minolta Air shields Transcutaneous bilirubinometer

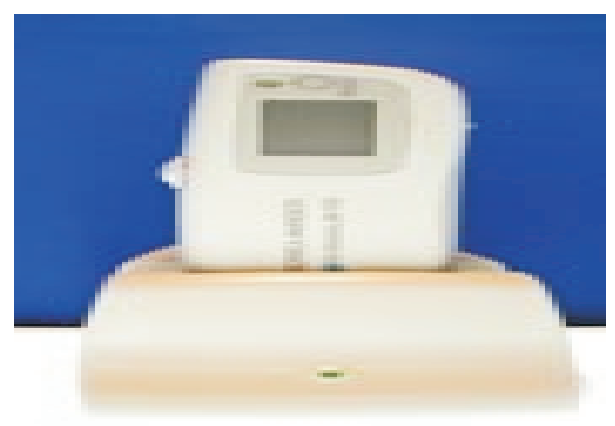

\section{MATERIAL AND METHODS}

This prospective study was conducted in the neonatal unit of the department of Paediatrics at Kasturba Hospital, Manipal. Study period was from October 2007 to June 2008. Healthy term neonates from birth upto day seven (7) postnatal age with jaundice were included in the study.

Term neonates were included in the study where visual observation of jaundice by trained paediatric postgraduate raised concern for risk of hyperbilirubinemia and necessitated serum bilirubin determination. Clinical assessment of jaundice was done in each baby in diffuse natural day light by observer, based on Kramer's index.

Transcutaneous bilirubin assessment was done on the forehead and sternum of each baby using JM-103 Minolta Air shields bilirubinometer. Serum bilirubin level was measured within 30 minutes of the clinical assessment for each baby. Specificage in hours at the time of study was recorded along with birth weight and gender.

All Transcutaneous bilirubin assessments were performed by one investigator using JM-103 Minolta Air shields bilirubinometer. The fibre optic probe was placed against the forehead and sternum of the infant in supine position. Gentle pressure was applied during measurement to ensure an event contact of the probe and skin. These three (3) consecutive 
scans were performed and a computerized mean value was displayed as transcutaneous bilirubin in $\mathrm{mg} / \mathrm{dl}$. Total serum bilirubin (TsB) was measured by clinical laboratory method by using direct spectral method.

\section{RESULTS}

Correlation between transcutaneous bilirubinometer (forehead) and total serum Bilirubin measurement

Table 1: Correlation between TcB and TcB value

\begin{tabular}{|l|l|l|l|}
\hline S.No. & Mg/dl & Mg/dl & $\begin{array}{l}\text { Correlation } \\
\text { coefficient (r) }\end{array}$ \\
\hline 1. & Clinical assessment & Total serum bilirubin & 0.757 \\
\hline 2. & TcB (forehead) & Total serum bilirubin & 0.798 \\
\hline 3. & TcB (sternum) & Total serum bilirubin & 0.801 \\
\hline
\end{tabular}

The correlation coefficient between clinical assessment, TcB forehead and sternum with total serum bilirubin values were significant $(r=0.757, r=0.798, r=0.801$ respectively, $\mathrm{p}>0.0001)$.

Table 2: Comparison between transcutaneous bilirubinometer (forehead) versus total serum bilirubin

\begin{tabular}{|c|c|c|c|c|c|c|c|}
\hline S.No. & $\begin{array}{l}\text { Forehead }(\mathrm{mg} / \mathrm{dl}) \\
\mathrm{n}=187\end{array}$ & $\begin{array}{l}6-7.9 \\
n=10\end{array}$ & $\begin{array}{l}8-9.9 \\
n=26\end{array}$ & $\begin{array}{l}10-11.9 \\
N=53\end{array}$ & $\begin{array}{l}12-13.9 \\
N=40\end{array}$ & $\begin{array}{l}14-15.9 \% \\
\mathrm{~N}=40\end{array}$ & $\begin{array}{l}16-17.9 \\
n=18\end{array}$ \\
\hline 1. & $\begin{array}{l}6-7.9 \\
n=8\end{array}$ & $\begin{array}{l}5 \\
50.0 \%\end{array}$ & $\begin{array}{l}3 \\
11.5 \%\end{array}$ & 0 & 0 & 0 & 0 \\
\hline 2. & $\begin{array}{l}8-9.9 \\
n=32\end{array}$ & $\begin{array}{l}4 \\
40.0 \% \\
\end{array}$ & $\begin{array}{l}12 \\
46.2 \% \\
\end{array}$ & $\begin{array}{l}12 \\
22.6 \% \\
\end{array}$ & $\begin{array}{l}2 \\
5 \%\end{array}$ & $\begin{array}{l}2 \\
5 \% \\
\end{array}$ & 0 \\
\hline 3. & $\begin{array}{l}10-11.9 \\
\mathrm{n}=49\end{array}$ & $\begin{array}{l}1 \\
10 \%\end{array}$ & $\begin{array}{l}10 \\
38.5 \% \\
\end{array}$ & $\begin{array}{l}24 \\
45.3 \% \\
\end{array}$ & $\begin{array}{l}11 \\
27.5 \% \\
\end{array}$ & $\begin{array}{l}3 \\
7.5 \% \\
\end{array}$ & 0 \\
\hline 4. & $\begin{array}{l}12-13.9 \\
\mathrm{n}=55\end{array}$ & 0 & $\begin{array}{l}1 \\
3.8 \% \\
\end{array}$ & $\begin{array}{l}14 \\
26.4 \% \\
\end{array}$ & $\begin{array}{l}19 \\
47.5 \% \\
\end{array}$ & $\begin{array}{l}18 \\
45 \%\end{array}$ & $\begin{array}{l}3 \\
16.7 \% \\
\end{array}$ \\
\hline 5. & $\begin{array}{l}14-15.9 \\
\mathrm{n}=36\end{array}$ & 0 & 0 & $\begin{array}{l}2 \\
3.8 \% \\
\end{array}$ & $\begin{array}{l}8 \\
20 \% \\
\end{array}$ & $\begin{array}{l}16 \\
40 \% \\
\end{array}$ & $\begin{array}{l}10 \\
55.6 \% \\
\end{array}$ \\
\hline 6. & $\begin{array}{l}16-17.9 \\
n=7\end{array}$ & 0 & 0 & $\begin{array}{l}1 \\
1.9 \%\end{array}$ & 0 & $\begin{array}{l}1 \\
2.5 \%\end{array}$ & $\begin{array}{l}5 \\
27.8 \%\end{array}$ \\
\hline
\end{tabular}

The accuracy of $\mathrm{TcB}$ (forehead) reading over forehead was $50 \%, 46.2 \%, 45.3 \%, 47.5 \%, 40 \%$ and $27.8 \%$ in range of $6-$ $7.9 \mathrm{mg} / \mathrm{dl}, 8-9.9 \mathrm{mg} / \mathrm{dl}, 10-11.9 \mathrm{mg} / \mathrm{dl}, 12-13.9 \mathrm{mg} / \mathrm{dl}, 14-15.9$ $\mathrm{mg} / \mathrm{dl}$ and $16-17.9 \mathrm{mg} / \mathrm{dl}$ respectively.

Forehead assessment of transctuaneous bilirubin with serum bilirubin showed strong correlation in the respective group categories.
Table 3: Comparison between transcutaneous bilirubinometer (sternum) with total serum bilirubin

\begin{tabular}{|c|c|c|c|c|c|c|c|}
\hline S.No. & $\begin{array}{l}\text { Sternum (mg/dl) } \\
\mathrm{n}=187\end{array}$ & $\begin{array}{l}6-7.9 \\
n=10\end{array}$ & $\begin{array}{l}8-9.9 \\
n=26\end{array}$ & $\begin{array}{l}10-11.9 \\
\mathrm{~N}=53\end{array}$ & $\begin{array}{l}12-13.9 \\
\mathrm{~N}=40\end{array}$ & $\begin{array}{l}14-15.9 \% \\
\mathrm{~N}=40\end{array}$ & $\begin{array}{l}16-17.9 \\
n=18\end{array}$ \\
\hline 1. & $\begin{array}{l}6-7.9 \\
n=6\end{array}$ & $\begin{array}{l}5 \\
50.0 \% \\
\end{array}$ & $\begin{array}{l}1 \\
3.8 \% \\
\end{array}$ & 0 & 0 & 0 & 0 \\
\hline 2. & $\begin{array}{l}8-9.9 \\
n=33\end{array}$ & $\begin{array}{l}4 \\
40.0 \% \\
\end{array}$ & $\begin{array}{l}13 \\
50 \% \\
\end{array}$ & $\begin{array}{l}13 \\
24.5 \%\end{array}$ & $\begin{array}{l}1 \\
2.5 \% \\
\end{array}$ & $\begin{array}{l}2 \\
5 \%\end{array}$ & 0 \\
\hline 3. & $\begin{array}{l}10-11.9 \\
n=40\end{array}$ & $\begin{array}{l}1 \\
10 \% \\
\end{array}$ & $\begin{array}{l}10 \\
38.5 \%\end{array}$ & $\begin{array}{l}21 \\
39.6 \% \\
\end{array}$ & $\begin{array}{l}8 \\
20 \% \\
\end{array}$ & 0 & 0 \\
\hline 4. & $\begin{array}{l}12-13.9 \\
\mathrm{n}=50\end{array}$ & 0 & $\begin{array}{l}2 \\
7.7 \% \\
\end{array}$ & $\begin{array}{l}15 \\
28.3 \% \\
\end{array}$ & $\begin{array}{l}17 \\
42.5 \%\end{array}$ & $\begin{array}{l}16 \\
40 \% \\
\end{array}$ & 0 \\
\hline 5. & $\begin{array}{l}14-15.9 \\
\mathrm{n}=46\end{array}$ & 0 & 0 & $\begin{array}{l}3 \\
5.7 \% \\
\end{array}$ & $\begin{array}{l}14 \\
35 \% \\
\end{array}$ & $\begin{array}{l}18 \\
45 \% \\
\end{array}$ & $\begin{array}{l}11 \\
61.1 \% \\
\end{array}$ \\
\hline 6. & $\begin{array}{l}16-17.9 \\
n=12\end{array}$ & 0 & 0 & $\begin{array}{l}1 \\
1.9 \%\end{array}$ & 0 & $\begin{array}{l}4 \\
10 \%\end{array}$ & $\begin{array}{l}7 \\
38.9 \%\end{array}$ \\
\hline
\end{tabular}

The accuracy of $\mathrm{TcB}$ reading over sternum was $50 \%$ in $\mathrm{TsB}$ range of 6-7.9 $\mathrm{mg} / \mathrm{dl}$ and $8-9.9 \mathrm{mg} / \mathrm{dl}$. In the other TsB ranges, the accuracy varied from $38.9 \%$ to $45 \%$.

Sternum assessment of transcutaneous bilirubin with total serum bilirubin showed strong correlation in the respective group categories.

Table 4: Sensitivity and specificity of TcB (forehead) to predict TsB levels

\begin{tabular}{|l|l|l|l|}
\hline $\begin{array}{l}\text { Total Serum } \\
\text { Bilirubin }\end{array}$ & $\begin{array}{l}\text { Transcutaneous } \\
\text { bilirubinometer } \\
\text { (forehead) } \mathbf{~ m g / d l}\end{array}$ & Sensitivity & Specificity \\
\hline $10 \mathrm{mg} / \mathrm{dl}$ & 10.45 & $79.3 \%$ & $77.8 \%$ \\
\hline $12 \mathrm{mg} / \mathrm{dl}$ & 12.05 & $81.1 \%$ & $82.4 \%$ \\
\hline $13 \mathrm{mg} / \mathrm{dl}$ & 12.35 & $82.4 \%$ & $81.4 \%$ \\
\hline $15 \mathrm{mg} / \mathrm{dl}$ & 13.60 & $83.9 \%$ & $82.9 \%$ \\
\hline
\end{tabular}

The sensitivity and specificity of $\mathrm{TcB}$ at an increment of $1 \mathrm{mg} / \mathrm{dl}$ when compared to TsB levels of $10,12,13$ and 15 $\mathrm{mg} / \mathrm{dl}$ which were the hour specific thresholds that indicates the need for phototherapy.

As shown in this table sensitivity was equal to specificity for transcutaneous bilirubinometer cut off value of 10.45, 12.05, 12.35 and $13.60 \mathrm{mg} / \mathrm{dl}$. Thus predicting accurate correlation with total serum bilirubin reading and transcutaneous bilirubinometer reading at these four values.

Transcutaneous bilirubinometer (forehead) values between 10 to $15 \mathrm{mg} / \mathrm{dl}$ correlate accurately with total serum bilirubin. 


\section{CONCLUSION}

1. Visual assessment of jaundice by trained observer based on Kramer's index could be used for screening purpose in neonatal jaundice.

2. Transcutaneous bilirubinometer assessment could be used for screening purpose of neonatal jaundice between 48 hours of age to 7 days of life.

3. Non invasive transcutaneous bilirubin assessment by JM-103 has demonstrated significant accuracy when compared to total serum bilirubin measured by clinical laboratory method. It can be favourably used as a screening test to identify the need for serum bilirubin measurement when transcutaneous bilirubin levels are more than $10,12,13,15 \mathrm{mg} / \mathrm{dl}$ at specific age in hours.

4. Transcutaneous bilirubinometer could be accurately used to measure bilirubin for screening purpose at two different sites namely forehead and sternum.

5. Transcutaneous bilirubinometer values between 10 $\mathrm{mg} / \mathrm{dl}$ to $15 \mathrm{mg} / \mathrm{dl}$ accurately measures total serum bilirubin. Hence, total serum bilirubin assessment based on blood sampling could be avoided between $10 \mathrm{mg} / \mathrm{dl}$ to $15 \mathrm{mg} / \mathrm{dl}$ of Transcutaneous bilirubinometer assessment.The measurement technique is rapid and simple. It is easy to perform repeated measurements over time. Thus reducing the like hood of error.

6. Transcutaneous bilirubinometer measurements beyond $15 \mathrm{mg} / \mathrm{dl}$ require to be correlated with total serum bilirubin levels.

\section{REFERENCES}

1. Madam A, MacMonon JR, Stevenson DK. Neonatal Hyperbilirubinemai.In: Taeush HW, Ballard RA, Gleason CV, editors.Avery's Diseases of the Newborn. *the d. Philadelphia: Saunders; 2005.p-1226-50.

2. Singh M. Jaundice-Causes of on the basis of age of onset Mehrban Singh ed. Care of the Newborn 6 thedition. NewDelhi. agar's publication 2004:p.241.

3. Clohert JP. Neonatal Hyperbilirubinemia. In: Cloherty JP, Eichenwald EC, Ann R. Stark, editors. Manual of Neonatal care. $5^{\text {th }}$ ed. Philadelphia; 2004.p. 185.

4. Stoll BJ, Liegman RM.Jaundice and Hyperbilirubinemia in the newborn. In; Behrman RE, Kliegman RM, Jenson HB, editors. Nelson text book of Pediatrics. $17^{\text {th }}$ ed. Philadelphia: Saunders, 2004.p.592.

5. Kramer LI. Advancement of dermal icterus in the jaundice newborn. Am J Dis child 1969; 118:454-58.

6. Yamanouchi I, Yamauchi Y, Igarashi I. Transcutaneous Bilirubinometry: Evaluation of Accuracy and Reliability in a Large Population.Acta Pedatr Scand 1988; 77:791-795.
7. Hegyi T, Hiatt IM, Indyk L. Transcutaneous bilirubinometry Correlations in term infants. J Pediatr 1981;98:454-57.

8. Maisels JM. Neonatal hyperbilirubinemia. In Lightner DA, McDonagh AF. Biosynthesis of bilirubin. $5^{\text {th }}$ edition. Philadelphia: Saunders WB; 2001.p.324-25.

9. Maisels MJ. Neonatal Jaundice. In Mac Donald MG Seshia MMK, Mullet MD, eds. Neonatology: Pathophysiology and Management of the Newborn. Philadelphia, Pa: Lippincort C $o ; 2205: 768-846$

10. Kaplan M, Renbaum P, Levy-Lahad E, Hammerman C, Lahad A, Beutler E. Gilbert syndrome and glucose-6-phospahte dehydrogenase deficiency: A dose- dependent genetic interation crucial to neonatal hyperbilirubinemia. Proc Nat Acad Sci USA 1997; 94:121.28-32.

11. Robinson GC. Hereditary spherocytosis in infancy. J Pedatr 1957; 50:447.

12. Austin RF, Desforges JF.Hereditary elliptocytosi: A usual presentation of hemolysis in the newborn associated with transistor morphologic abnormalities. Pediatrics 1969 . 44:196-200.

13. Arias IM. Inheritable and congenital hyperbilirubinemai Models for the study of drug metabolism. N Engl J Med 1971, 285: 1416-21.

14. Child B, Sidbury JB, Migeon CJ. Glucoronic acid conjugation by patients with familiar non-hemolytic jaundice and their relatives. Pediatrics 1954; 23:908-13.

15. Sinaasappel $M$, Jansen PL. The differential diagnosis of Crigler Najjar diseases, type 1 and 2, by bile pigment analysis. Gastroenterology 1991; 100:783-89.

16. Berk PD. Update on bilirubin metabolism. Recent advances in Hepatology. 1986; 2:13.

17. Bhutani VK, Johnson LH. Diagnosis and management of hyperbilirubinemia in the term neonates for a safer first week, pediatr Clin NAm 2004; 51:843-861.

18. Cockington RA. A guide to the use of phototherapy in the management of neonatal hyperbilirubinemia. J pediatr 1979; $95 ; 2 ; 281-85$.

19. Yasuda $S$, Itoh $S$, Isobe $K$, et al. New transcutaneous jaundice device with two optical paths. JPerinat Med. 2003; 31:81-88.

20. Ho HT, Ng TK, Tsui KC, Lo YC. Evaluation of a new transcutaneous bilirubinmeter in Chinese newborns. Archives of disease in childhood-Fetal and neonatal Edition 2006; 91: F 434-38.

21. Sapavat S, Nuchprayoon I. Non invasive transcutaneous bilirubin as a screening test to identify the serum bilirubin assessment; JMed Assoc Thai 2004; 97:1193-98.

22. Maisels MJ, Ostrea EM jr, Touch $S$ et al. Evaluation of a new transcutaneous bilirubinometer. Pediatrics 2004; 113. 1628-35. 
23. Randeberg LL, Roll EB, Nilsen LTN, Christensen T, Svaasand $L O$. In vivo spectroscopy of jaundiced newborn skin reveals more than a bilirubin index. Acta Paediatr 2005; 94:65-71.

24. Karyn B, Kolman MD, Kathleen M, Mathieson, Carlos Frias. A comparison of transcutaneous and total serum bilirubin in newborn Hispanic infants at 35 or more weeks of gestation. American Board of family medicine 2007; 20:3:266-271.

25. Riskin A, Kuglman A, Abend WM, Green M, Hemo A, Bader $D$, in the eye of the beholder: how accurate is clinical estimation of jaundice in newborns. Acta Pediatr 2203; 92:574-76.

26. American Academy of Pediatrics. Practice Parameter, Management of Hyperbilirubinemia in the Healthy Term Newborn. Pediatrics 1999; 94: 558-65.

27. Petersen JR, Okoredudu AO, Mohammad AA, Fernando A, Shattuck KE. Association of transcutaneous bilirubin testing in hospital with decreased readmission rate for hyperbilirubinemia. Clin Chem 2005; 51:540-544.

28. Moyer VA, Ahn C, Sneed S. Accuracy of clinical judgement in neonatl jaundice. Arch Pediatr Adolesc Med. 2000; 154:391-4.

29. Singh M. Nomenclature and Definitions gestational age groups. In Meherabn Singh ed. Care of the Newborn $6^{\text {th }}$ edition. New Delhi: Sagar Spublication; 2004. P:2.

30. Ballard JL, Novak KK, Driver M. A simplified score for assessment of fetal maturation of newborn infants. J pediatr 1979; 9: 769-74.
31. Briscoe L, Clark S, Yoxall C. Can transcutaneous bilirubinometry reduce the need for blood tests in jaundice full term babies? Arch Dis child fetal Neonatal Ed. 2002;86:F 190-92.

32. Maisels JM. Neonatal Hyperbilirubinemia. In MH Klaus, Fanaroff AA eds. Care of high risk neonate. $5^{\text {th }}$ edition. Philadelphia; WB Saunders; 2001.p:324-25.

33. Jeffrey $M$, Maisels MB, Neonatal jaundice Pediatrics in Review 2006; 27:443-452.

34. Moyer VA, An C, Sneed S. Accuracy of clinical judgement in neonatal jaundice. Arch pediatr Adolesc Med 2000: 154. $391-94$

35. American Academy of Pediatrics, Subcommittee on Hyperbilirubinaemia. Management of hyperbilirubinemia in the newborn infant 35 or more weeks of gestation. Pediatrics 2004; 114: 297-316.

36. Robertson A, Kazmierczak, Vos P. Improved transcutaneous bilirubinometry: Comparison of Spect Rx Bilicheck and Minolta jaundice Meter JM-102 for estimating total serum bilirubin in a normal newborn population. J Perinatol 2002, 22: 12-14.

37. Grohmann K, Roser M, Rolinski B et al. Bilirubin measurement for neonates: Comparison of 9 frequently used methods. Pediatrics 2006; 117:1174-83. 